\title{
Pengaruh Akuntabilitas, Transparansi, dan Partisipasi Masyarakat Terhadap Pengelolaan APBDesa
}

\author{
Merisa Oktaria ${ }^{1, *}$, Rinto Alexandro ${ }^{2}$ \\ 1 Universitas Palangka Raya; merisa.oktaria@fkip.upr.ac.id \\ * Corres pondence a uthor: merisa.oktaria@fkip.upr.ac.id; Tel.: +62852493993XX
}

\begin{abstract}
The village is a social institution that has a very importa ntpositionandhas veryclosedirectinteractions with the community. The village is an a utonomous institution with its own traditions, customs andlaws thatare deeply rooted and relatively independent from interference from powers outside the institution. This research has its own reasons for choosing the APBDesa program for this interest because the APBDesa has major implications for the development of a region. The method us ed in this res earch is qua ntitativemethod. Thetype of data used in this research is quanti tative data, namely, data in the form of numbers and questionnaire assistance to obtain answers to the research objectives. The population in thisstudywas thevillagegovernment of Tewang Karangan totaling 36 people and the population based on the KK of 489 people.Thesampleis partof the number and characteristics possessed by the population with the sampling technique using purposive sampling. The analytical tool used is multiple linear analysis using the SPSS 25 program.
\end{abstract}

Keywords: Accountability, Transparency and Community Participation

\section{Pendahuluan}

Indonesia sebagai suatu Negara yang di bangun sebagai kepemerintahan yang dianggap paling atas dari desa, dan desa merupakan pelopor sistem demokrasi yang otonom dan berdaulat penuh. Desa merupakan instansi sosial yang mempunyai posisi sangat penting dan sangata dekat langsung berinteraksi dengan masyarakat. Desa merupakan lembaga otonom dengan tradisi, adat istiadat dan hukumnya sendiri yang mengakar kuat serta relatif mandiri dari campur tangan kekuasaan diluar lembaga itu. Menurut hukum Undang-Undang No. 6 Tahun 2014 tentang desa, yang dimaksud dengan desa adalah disebut sebagai desa adat atauyang disebut dengan nama lain, selanjutnya disebut desa, adalah karna kesatuan masyarakat hukum yang memiliki batas wilayah yang berwenang untuk mengatur dan mengurus urusan pemerintahan, kepentingan masyarakat setempat berdasarkan prakarsa masyarakat, hak asal usul, dan/atau hak tradisional yang diakui dan dihormati dalam sistem pemerintahan Negara Kesatuan Republik Indonesia. Penelitian ini memiliki alasan tersendiri dalam memilih program APBDesa ketertarikan ini dikarenakan APBDesa memiliki implikasi yang besar dalam pembangunan sebuah daerah. Faktor lain yang mendorong penulis dalam melakukan penelitian mengenai variabel akunta bilitas, transparansi dan partisipasi masyarakat dalam pengelolaan APBDesa, karena peneliti ingin mendeskripsikan dan menjelasakan dan melihat pengaruhnya variabel independen terhadap variabel dependen dalam pengelolaan APBDesa. Jika Semua anggaran direalisasikan dengan baik dan jujur maka hasil pembangunan juga terlihat dengan jelas begitupun sebaliknya. Tujuan penelitian ini adalah untuk mengetahui pengaruh akuntabilitas, transparansi dan partisipasi masyarakat terhadap pengelolaan APBDesa Pada Desa Tewang Sanggaring, Kecamatan Pulau Malan Kabupaten Katingan. Menurut Lembaga Administrasi Negara dan Badan Pengawasan Keuangan dan Pembangunan RI (2015), dalam Subroto: (2011) Akuntabilitas adalah kewajiban untuk memberikan pertanggungjawaban atau menjawab dan menerangkan kinerja dan tindakan seseorang/pimpinan suatu unit organisasi kepada pihak yang memiliki hak atau yang berwenang meminta pertanggungjawaban. Menurut Mardiasmo, (2011:32) Transparansi berarti keterbukaan 
(openness) pemerintah dalam memberikan informasi yang terkait dengan aktivitas pengelolaan sumber daya publik kepada pihak-pihak yang membutuhkan informasi Transparansi di sini memberikan arti bahwa anggota masyarakat memiliki hak dan akses yang sama untuk mengetahui proses anggaran karena menyangkut aspirasi dan kepentingan masyarakat dalam proses pembangunan desa. Dalam Permendagri No. 37 Tahun 2007 Tentang Pengelolaan Keuangan Desa, partisipasi memakai kata-kata partisipatif, adalah setiap warganegara mempunyai suara dalam pembuatan keputusan, baik secara langsung maupun melalui intermediasi institusi legitimasi yang mewakili kepentingannya. Menurut Halim, (2008: 20). Anggaran Pendapatan dan Belanja Desa dapat di definisikan sebagai rencana operasional keuangan pemerintah daerah, dimana ada satu pihak menggambarkan perkiraan pengeluaran yang setinggi-tingginya guna membiayai kegiatan dan proyek daerah selama satu tahun anggaran tertentu dan pihak lain menggambarkan perkiraan sumbersumber penerimaan daerah guna menutupi pengeluaran-pengeluaran tersebut.

\section{Metode}

Metode yang digunakan dalam penelitian ini yaitu Metode kuantitatif yang lebih menitikberatkan pembuktian hipotesis dalam bentuk hubungan variabel. Menurut Sugiyono: 2017:8) Metode pendekatan kuantitatif adalah metode yang berlandaskan pada filsafat dan positivisme, digunakan untuk meneliti pada populasi atau sampel tertentu, teknik pengambilan sampel umumnya dilakukan secara random, pengumpulan data menggunakan koensioner penelitian, analisis data bersifat kuantitatif/statistik dengan tujuan untuk menguji hipotesis yang ditetapkan dengan menenkankan pada adanya variabel-variabel sebagai objek penelitian, dan dengan melalui hipotesis yang dibangun maka akan diuji dengan formula statistik dan teknik analisis tertentu. Populasi dalam penelitian ini adalah pemerintah desa Tewang Karangan berjumlah 36 orang dan jumlah penduduk berdasarkan KK 489 jiwa. Sampel adalah bagian dari jumlah dan karakteristik yang dimiliki oleh Populasi tersebut dengan Teknik penentuan sampel menggunakan Purposive Sampling. Dengan total populasi penlitian adalah pemerintah desa berjulah 36 orang dan masyarakat desa berdasarkan KK berjumlah 564 jiwa. Dimana purposive sampling dinyatakan sebagai teknik penentuan sampel dengan menggunakan pertimbangan tertentu yang berasal dari populasi penellitian yaitu berikut kriteria penelitian desa yang mengunakan teknik purposive sampling yang terpilih untuk di jadikan sampel penelitian adalah pemerintah Desa Tewang Karangan:

1) Aparatur Desa Tewang Karangan.

2) Semua unit kegiatan pemerintahan dalam pengelolaan APBDesa dan Pembangunan Desa Tewang Karangan.

3) Tokoh Mayarakat Desa (Mantir adat dan Tokoh Agama).

4) Pengawas Desa dari Kecamatan Pulau Malan.

Jenis data yang digunakan dalam penelitian ini adalah data kuantitatif yaitu, data yang berupa angka dan bantuan koesioner untuk mendapatkan jawaban dari tujuan penelitian. Sumber data yang digunakan dalam penelitian ini adalah data primer dan data sekunder. Data primer adalah data yang diperoleh melalui media penyebaran koesioner (angket penelitian) seputar pernyataan koesioner yang diajukan kepada responden penelitian. Data sekunder adalah data berupa bukti, catatan atau laporan historis yang tersusun dalam arsip yang di publikasikan. Teknik pengumpulan data dalam penelitian ini adalah data kuantitatif dengan melakukan penyebaran angket penelitian untuk memperoleh jawaban responden atas beberapa item pertanyaan tentang pengaruh akuntabilitas, transparansi dan partisipasi masyarakat terhadap Pengelolaan APBDesa. 
Gambar 1. Model Penelitian

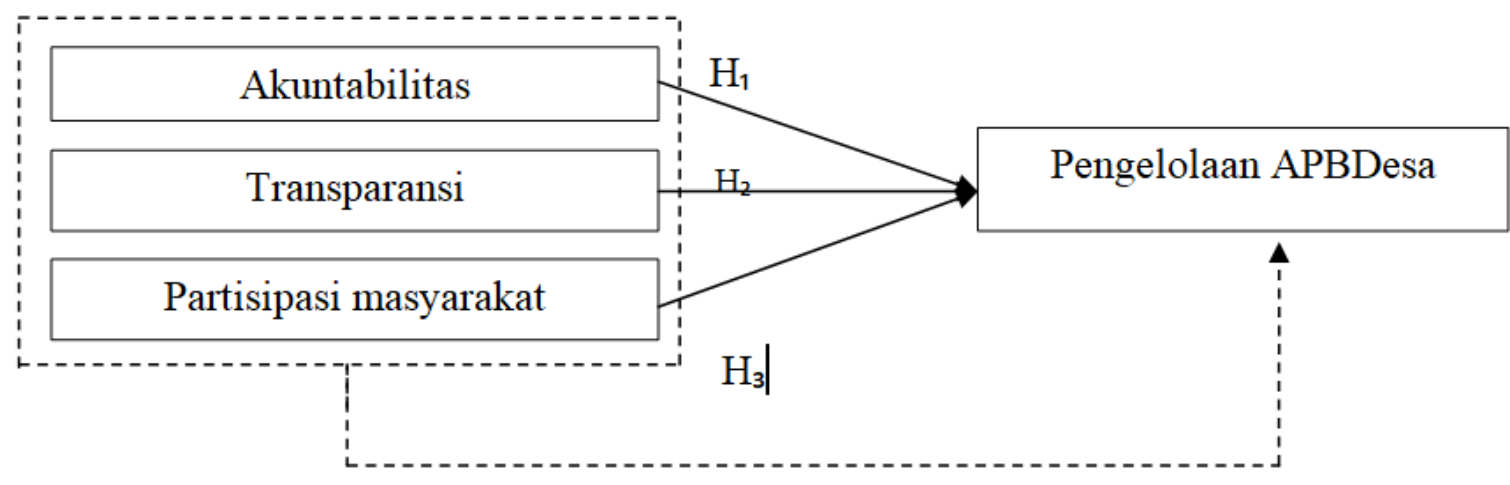

Keteragan :

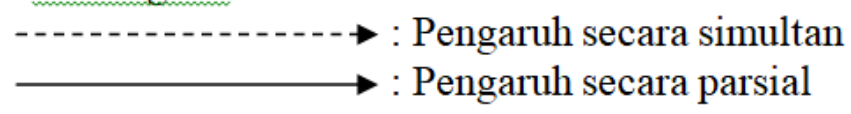

Metode analisis yang digunakan dalam penelitian ini adalah dengan mengunakan metode analisis regresi linier berganda untuk memperoleh gambaran yang menyeluruh mengenai suatu hubungan antara variabel satu, dengan variabel yang lain. Dalam hal ini untuk variabel independen pengaruh akuntabilitas transparansi, dan Partisipasi masyarakat sedangkan untuk variabel dependen adalah pengelolaan APBDesa. Koesioner dalam penelitian ini dikembangkan oleh (Sri Lestari: 2016) yang digunakan untuk mengukur bentuk keterbukaaan dalam rangka peran dari APBDesa sehingga dapat di ketahui dan di awasi bersama. Dengan pengukuran sebagai bahan untuk mengetahui ada tidaknya pengaruh yang signifikan dari variabel independen terhadap variabel dependen. Uji statistik regresi linier berganda dikatakan model yang baik jika model tersebut memenuhi asumsi normalitas, validitas dan reliabilitas model persamaannya sebagai berikut:

$$
Y=\alpha+\beta 1 X_{1}+\beta 2 X_{2}+\beta 2 X_{3}+e
$$

Keterangan:

$Y=$ Pengelolaan APBDesa

$\alpha=$ Konstanta

$\beta=$ Koefisien regresi

$\mathrm{X}_{1}=$ Akuntabilitas

$\mathrm{X}_{2}=$ Transparansi

$\mathrm{X}_{3}=$ Partisipasi Masyarakat

$\mathrm{e}=$ Residual (variabel kesalahan)

Jika dalam perhitungan statistik pengujian disebut signifikan apabila suatu nilai dari statistiknya berada pada situasi kritis (HO ditolak), dan pengujian pada nilai statistik (Ha Diterima), maka pengujian ini dapat ditulis sebagai berikut:

1. Jika nilai signifikan dari pengujian bernilai $>0,05 \mathrm{Maka} \mathrm{H}$ ) diterima dan Ha ditolak

2. Jika nilai signifikan pengujian bernilai $<0,05$ Maka HO ditolak dan Ha di terima. 


\section{Hasil Penelitian dan Pembahasan}

Desa Tewang Karangan merupakan bagian dari Kecamatan Katingan Tengah, Kabupaten Katingan Provinsi Kalimantan Tengah. Batas Desa Tewang Karangan meliputi bagian sebelah utara Desa Tbg Tanjung/Tbg Tungku bagian sebelah timur yaitu Desa Kabupaten Gunung Mas, dibagian sebelah selatan yaitu Desa Tbg Lawang/Dahian Tunggal dan bagian sebelah barat yaitu Desa Desa Tbg Tungku/Geragu/Kali Katingan. Sesuai dengan kondisi desa yang merupakan daerah agraris maka struktur ekonominya lebih dominan kepada Sektor Pertanian dan petambangan, di samping sektorsektor lainnya baik berupa jasa industri, perkebunan, peternakan, pertukangan dan pengusaha swasta. Biografis sejarah data yang menggambarkan keadaan desa Tewang Karangan adalah:

1) Monografi Desa

Tabel 1. Monografi Desa Tewang Karangan

\begin{tabular}{|c|c|c|}
\hline No & \multicolumn{2}{|r|}{ Uraian } \\
\hline 1 & \begin{tabular}{|l} 
Luas wilayah :1 \\
1. S1 $2738.0 \mathrm{E}$ \\
2. S1 $2814.8 \mathrm{E}$ \\
3. S1 $3131.9 \mathrm{E}$ \\
4. $\mathrm{S} 13209.0 \mathrm{E}$ \\
5. S1 $3536.0 \mathrm{E}$ \\
6. S1 $3533.0 \mathrm{E}$ \\
7. S1 $3439.0 \mathrm{E}$ \\
8. S1 $3009.0 \mathrm{E}$
\end{tabular} & $\begin{array}{l}\text { 04 Hektar/Dengan titik kordinat: } \\
31929.0 \\
32005.3 \\
32139.6 \\
32320.0 \\
31454.0 \\
1304.0 \\
31410.0 \\
31439.0\end{array}$ \\
\hline 2 & $\begin{array}{l}\text { a) Jumlah RT } \\
\text { b) Jumlah RV } \\
\text { c) Jumlah KK } \\
\text { d) Jumlah Per } \\
\text { e) Jumalah Pe }\end{array}$ & 6 \\
\hline 3 & \begin{tabular}{|ll}
\multicolumn{2}{|c}{ Batas wilayah : } \\
a. & Utara \\
b. & Selatan \\
c. & Barat \\
d. & Timur
\end{tabular} & $\begin{array}{l}\text { Desa Tbg Tanjung/Tbg Tungku } \\
\text { Desa Tbg Lawang/Dahian Tunggan } \\
\text { Desa Tbg Tungku/Geragu/Kali Katingan } \\
\text { Desa Kabupaten Gunung Mas }\end{array}$ \\
\hline 4 & $\begin{array}{l}\text { Topografi: } \\
\text { a) Luas kemirir } \\
\text { b) Ketinggian c }\end{array}$ & $\begin{array}{l}\text { lahan (rata-rata) } \\
\text { as permukaan laut (rata-rata) } 3 \mathrm{~m}\end{array}$ \\
\hline 5 & Hidrologi : - & \\
\hline 6 & \begin{tabular}{|l} 
Klimatologi : \\
a) Suhu \\
b) Curah Huj \\
c) Kelembab \\
d) Kecepatar
\end{tabular} & 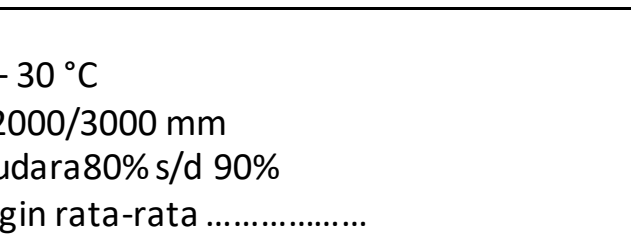 \\
\hline
\end{tabular}




\begin{tabular}{c|l}
\hline 7 & $\begin{array}{l}\text { Luas lahan pertanian: } \\
\text { a) Sawah teririgasi : } \mathrm{Ha} \\
\text { b) Sawah tadah hujan }: 150 \mathrm{Ha}\end{array}$ \\
\hline 8 & Luas lahan pemukiman :100 Ha \\
\hline 9 & Kawasan rawan bencana: Banjir : $300 \mathrm{Ha}$ \\
\hline
\end{tabular}

Sumber: Profil Desa Tewang Karangan, Tahun 2019

Analisis regresi bertujuan untuk mengetahui besarnya pengaruh yang ditimbulkan antara pengaruh akuntabilitas, transparansi, dan partisipasi masyarakat dalam pengelolaan APBDesa secara bersama-sama dengan menggunakan persamaan regresi berganda sebagai berikut:

Tabel 2. Regresi Linier Berganda

\begin{tabular}{l|r|r|r|r|r}
\hline \multirow{2}{*}{ Model } & \multicolumn{2}{|c|}{$\begin{array}{c}\text { Ustandarnized } \\
\text { coeffecients }\end{array}$} & $\begin{array}{c}\text { Standarnized } \\
\text { coefficients }\end{array}$ & \multirow{2}{*}{ T } & \multirow{2}{*}{ Sig. } \\
\cline { 2 - 4 } & \multicolumn{1}{c|}{ B } & Std. Error & \multicolumn{1}{c|}{ Beta } & & \\
\hline 1. (Constant) & 26.087 & 14.083 & & 7.032 & .000 \\
\hline Akuntabilitas $\left(X_{1}\right)$ & 446 & 426 & 351 & 2.824 & 007 \\
\hline Transparansi $\left(X_{2}\right)$ & 584 & 436 & 420 & 2.990 & .006 \\
\hline Partisipasi Masyarakat $\left(X_{3}\right)$ & 454 & 343 & 313 & 3.246 & .005 \\
\hline
\end{tabular}

Sumber : Data Diolah SPSS versi 20,0

Berdasarkan tabel 2 di atas menunjukkan persamaan regresi linear berganda dapat sebagai berikut :

$$
Y=26,087+0,446 X 1+0,584 X 2+0,454 X 3+e
$$

Berdasarkan hasil analisis regresi linier berganda maka akuntabilitas diperoleh nilai koefesien regresi sebesar 2.824 dengan tingkat signifikasi $446<0,05$, hasil pengujian menunjukkan bahwa akuntabilitas (X1) memiliki nilai pengaruh signifikan positif terhadap pengelolaan APBDesa maka hipotesis pertama Ho diterima dan Ha ditolak dengan koefesien regresi menunjukkan hasil 0.007 dapat diartikan bahwa akuntabilitas (pertanggungjawaban) berpengaruh positif terhadap pengelolaan APBDesa. Berdasarkan hasil analisis regresi linier berganda maka variabel transparansi diperoleh nilai koefisien regresi sebesar 2.990 dengan tingkat signifikasi sebesar $0.584>0,05$ jadi dapat diartikan bahwa transparansi yang dinyatakan sebagai variabel (X2) memiliki nilai pengaruh yang positif signifikan terhadap pengelolaan APBDesa maka hipotesis ke dua Ho diterima dan Ha ditolak. Berdasarkan penjelasan hasil dari koefisien regresi yang menunjukkan hasil analisis sebesar 0.584. Diartikan transparansi (keterbukaan) memiliki pengaruh positif signifikan terhadap pengelolaan APBDesa. Mengapa dinyatakan berpengaruh Positif signifikan karena variabel transparansi atau keterbukaan sudah melaksanakan pengelolaan APBDesa yang dilaporkan ke kabupaten/kota sudah sesuai dengan ketentuan dan peraturan yang berlaku dan keterbukaan atas informasi kepada masyarakat desa dengan menggunakan media papan pengumuman dan informasi keuangan melalui rapat dan spanduk yang dipajang didepan kantor desa dan persimpangan desa dan spanduk kegiatan realisasi program yang dibiayai dengan menggunakan anggaran APBDesa. Berdasarkan hasil analisis regresi linier berganda maka variabel transparansi diperoleh nilai koefisien regresi sebesar 3.246 dengan tingkat signifikasi sebesar $0.454>0,05$ ja di da pat diartikan bahwa transparansi yang dinyatakan 
sebagai variabel (X2) memiliki nilai pengaruh yang positif signifikan terhadap pengelolaan APBDesa maka hipotesis ke dua Ho diterima dan Ha ditolak. Berdasarkan penjelasan hasil dari koefisien regresi yang menunjukkan hasil analisis sebesar 0.454. Diartikan bahwa partisipasi masyarakat telah dilaksanakan bersama dengan bukti yang dapat dilihat dan dinilai oleh peneliti pada saat melaksanakan penelitian pada desa Tewwang Karangan. Dimana partisipasi masyarakat desa dapat diukur melalui tenaga, material dan gotog royong dalam menjalankan pembangunan dan program desa. dengan adanya partisipasi dari masyarakat desa dalam membantu dan mengawasi pembangunan dan pengelolaan APBDesa maka desa akan dianggapaman dari kegiatan penyalah gunaan keuangan desa Karena masyarakat desa aktif dalam membantu dan berpartisipasi dalam kegiatan desa dan membangun desa sesuai dengan program desa. Berdasarkan indikator pendukung dalam penelitian ini dinyatakan bahwa Partisipasi masyarakat adalah sebagai bentuk keperdulian masyarakat desa dalam membangun desa dan menjadikan desanya sejahtera dengan mengandalkan keuangan desa yang diberikan kepada desa. Berdasarkan hasil analisis regresi linier berganda maka variabel transparansi diperoleh nilai koefisien regresi sebesar 7.032 dengan tingkat signifikasi sebesar 26.087> 0,05 jadi dapat diartikan bahwa variabel independen dalam penelitian ini secara bersama-sama memiliki pengaruh yang positif signifikan terhadap pengelolaan APBDesa yaitu sebeagai variabel dependen maka hipotesis ke dua Ho diterima dan Ha ditolak. Berdasarkan penjelasan hasil dari koefisien regresi yang menunjukkan hasil analisis sebesar 26.087. Diartikan bahwa variabel independen telah diterapkan dan dilaksanakan bersama dengan bukti yang dapat dilihat dan dinilai oleh peneliti pada saat melaksanakan penelitian pada desa Tewwang Karangan. Dimana partisipasi masyarakat desa dapat diukur melalui tenaga, material dan gotog royong dalam menjalankan pembangunan dan program desa. Dengan adanya partisipasi dari masyarakat desa dalam membantu dan mengawasi pembangunan dan pengelolaan APBDesa maka desa akan dianggap aman dari kegiatan penyalah gunaan keuangan desa Karena masyarakat desa aktif dalam membantu dan berpartisipasi dalam kegiatan desa dan membangun desa sesuai dengan program desa.

Hasil penelitian ini didukung oleh hasil penelitian yang dilakukan Ayundia Ati, (2014) dengan hasil penelitian yang menunjukkan bahwa pihak pemerintah desa belum terlalu terbuka dalam kegiatan pengelolaan anggaran pendapatan dan belanja desa kepada masyarakat desa karena masyarakat desa tidak memperdulikan segala kegiatan pemerintahan dan membantu pemerintah dalam menyukseskan pembangunan desa sesuai dengan a pa yang menjadi prioritas dan kebutuhan mendasar dari desa dan masyarakat desa. sehingga dari penelitiannya memberikan hasil bahwa variabel Transparasi sebagai variabel independen dinyatakan memiliki nilai pengaruh yang singifikan positif terhadap variabel dependen. Karena dalam proses perencanaan, pelaksanaan, pelaporan dan pertanggungjawaban anggaran sudah sesuai dengan ketentuan yang berlaku.

\section{Kesimpulan}

Penelitian ini menganalisis pengaruh akuntabilitas transparansi dan partisipasi masyarakat terhadap pengelolaan APBDesa. Penelitian ini dilakukan di Desa Tewang Karangan, Kecamatan Katingan Tengah Kabupaten Katingan Dengan responden pemerintah desa dan masyarakat desa yang berjumlah 45 responden (Sampel Penelitian).

\section{Akuntabilitas Berpengaruh Signifikan Positif Terhadap Pengelolaan APBDesa}

Akuntabilitas dalam pengelolaan dana APBDesa diperoleh nilai koefesien dari t hitung 2.824 dengan nilai signifikasi sebesar 0,007 hasil pengujian menunjukkan bahwa akuntabilitas (X1) memiliki nilai pengaruh signifikan positif terhadap pengelolaan APBDesa.

\section{Transparansi Berpengaruh SignifikanTerhadap Pengelolaan APBDesa}


Diperoleh nilai koefisien regresi sebesar 2.990 dengan tingkat signifikasi sebesar $0.584>0,05$ jadi dapat diartikan bahwa transparansi yang dinyatakan sebagai variabel (X2) memiliki nilai pengaruh yang positif signifikan terhadap pengelolaan APBDesa

3. Partisipasi Masyarakat Berpengaruh Signifikan Positif Terhadap Pengelolaan APBDesa Diperoleh nilai koefisien regresi sebesar 3.246 dengan tingkat signifikasi sebesar $0.454>0,05$ jadi dapat diartikan bahwa transparansi yang dinyatakan sebagai variabel (X3) memiliki nilai pengaruh yang positif signifikan terhadap pengelolaan APBDesa

4. Akuntabilitas, Transparansi, dan Partisipasi Masyarakat Berpengaruh Signifikan Positif Terhadap Pengelolaan APBDesa

Diperoleh nilai koefisien regresi sebesar 7.032 dengan tingkat signifikasi sebesar 26.087>0,05 jadi dapat diartikan bahwa variabel independen dalam penelitian ini secara bersama-sama memiliki pengaruh yang positif signifikan terhadap pengelolaan APBDesa

\section{DAFTAR PUSTAKA}

Adisasmita, 2013:28 Konsep tentang Akuntabilitas dan Implementasinya di Indonesia, Jakarta.

Arifiyanto, D.F dan Kurrohman, T, 2014. Akuntabilitas pengelolaan alokasi dana desa di Kabupaten Jember. Jurnal Riset Akuntansi dan Keuangan Volume 12 Nomor 2, Januari 2013: 94-103

Abdul Hamin, 2008:96. Tentang PAD penerimaan daerah dan sumber asli daerah. Jakarta.

Arikunto, S. 2012. Manajemen penelitian, Jakarta: Rineka Cipta.

Bambang, 2011:22. Peluang Pengembangan Partisipasi Masyarakat melalui Kebijakan Alokasi Dana Desa, Pengalaman Enam Kabupaten. Makalah disampaikan pada Pertemuan Forum Pengembangan Partisipasi Masyarakat (FPPM) di Lombok Barat 27-29 Januari 2005.

Dika Wahyuni, 2016. Jurnal Skripsi. Tentang Pengaruh Akuntabilitas dan Partisipasi Masyarakat Terhadap Pengelolaan Keuangan Desa di kabupaten Serang Banten.

Dwiyanto, Agus. 2015. Reformasi Birokasi Publik di Indonesia. Yogyakarta: Gajah Mada University Press.

Diantoro Kusumo, 2013. Skripsi Pull. Tentang transparansi keterbukaan pemerintah desa, Universitas Bandung.

Ellwood, 2016. dalam Mahsun, 2009. Tentang Akuntablitas Pelaksanaan Pertanggungjawaban Kewajiban. Jakarta.

Elgia Astuty, 2014. Jurnal Skripsi. Tentang Pegaruh akuntabilitas, transparansi dan Partisipasi Masyarakat terhadap pemerintah desa dalam pengelolaan APBDesa Untuk pembangunan desa.Surakarta.

Fanida, Eva Hany dan Elgia Astuti, 2012. Akuntabilitas Pemerintah Desa dalam Pengelolaan Anggaran Pendapatan dan Belanja Desa (APBDesa) (Study pada Alokasi Dana Desa Tahun Anggaran 2011 di Desa Sareng Kecamatan Geger Kabupaten Madiun.

Gozhali, 2016. Alat Uji determinasi Penelitian. Jakarta: Rineka Cipta

Goilford. 2013. Alat Uji Analisis Penelitian.Jakarta: Rineka Cipta.

Heru Rochmansjah dan Chabib Soleh, 2015:03. Skripsi. Tentang perencanaan dalam pengelolaan keuangan desa.

Hari Sabarno, 2011;10. Desentralisasi dan Otonomi Daerah (Desentralisasi, Demokratisasi, Akuntabilitas Pemerintah Daerah). Jakarta: LIPI Press.

Halim, Abdul dan Muhamad, Ikbal. 2012:83. Pengelolaan Keuangan Daerah. Yogyakarta: Sekolah Tinggi Ilmu Manajemen YKPN

Harjono Hery, 2016. Transparansi Pemerintahan Desa Dalam Penyusunan Anggaran Pendapatan dan Belanja Desa (APBDesa) Di Desa Long Nah Kecamatan Muara Ancalong Kabupaten Kuta i Timur", eJurnal Ilmu Pemerintahan

Iqsan, 2016. Desa sebagai kawasan otonom dalam Pengelolaan Keuangan Desa, Jakarta: LIPI Press.

Kurnia, 2016. Jurnal Skripsi. Tentang pengelolaan keuangan desa dalam pembangunan desa.

Kamendagri, No. 29 Tahun 2002. Tentang pedoman pengurusan dan pengawaasan keuangan desa. 
Linda Lestari, 2015. Jurnal. Skripsi. Tentang pengaruh akuntabilitas dan transparansi pertanggungjawaban APBDesa.

Lembaga Administrasi Negara dan Badan Pengawasan Keuangan dan Pembangunan Republik Indonesia, 2015 dalam Subroto, 2011. Akuntabilitas kewajiban memberikan pertanggungjawaban. Sekolah Tinggi Ilmu Manajemen. YKPN: Jakarta.

Lalolo, 2011:17 Tentang Akuntabilitas Finansial Perdesaan. Yogyakarta: Sekolah Tinggi Ilmu akuntansi Desa.

Mardiasmo, 2015.46. Tentang akuntabilitas kewajiban. Jakarta: Andy.

Moleong, Lexy J. 2014. Metode Penelitian Kualitatif, Bandung: PT. Remaja Rosdakarya

Mardiasmo, 2013. Otonomi Daerah dan Manajemen Keuangan Daerah. Yogyakarta: Andi.

Mardiasmo, 2010:24. Tentang penetapan otonomi daerah dalam MPR No. XV/MPR/1998.

Mahsun, 2008:46. Tentang anggaran APBDesa dalam pengeluaran dan penerimaan desa.

Muhamad Iqbal, 2015 dalam Abdul Halim 2015:83. Jurnal Skripsi. Akuntabilitas dalam memberikan pertanggungjawaban kinerja organisasi.

Mohamad Iqbal, 2015:84. Dimensi Akuntabilitas dalam suatu organisasi pertanggungjawaban. Bandung

Mardiasmo, 2017. Otonomi dan Manajemen Keuangan Daerah. www. kajianpustaka. com

Mardiasmo, 2014. Transaparansi sebagai bahan validasi premis pembangunan desa. www. Kajianpustaka. com

Nurdiawan, 2011. Tentang PADesa dalam penyajian informasi keuangan.

Nurcholis, Hanif, 2011. Pertumbuhan \& penyelenggaraan pemerintahan desa. Jakarta : Erlangga.

Peraturan Menteri Dalam Negeri Republik Indonesia Nomor 47 Tahun 2015 Tentang Kader Pemberdayaan Desa.

Peraturan Menteri Dalam Negeri (Pemendagri).. No. 13 Tahun 2006. Tentang Pengelolaan keuangan Desa

Paul H Landis. 2014:12. Tentang Kelompok belanja transfer dalam pengeluaran dana desa,

Priyatno Dwi, 2012. Metode Uji Penelitian. LP3ES. Jakarta. 2012:137-139

Peraturan Menteri Dalam Negeri (Pemendagri). No. 113 Tahun 2014. Pasal 1 ayat 6. Tentang Pengukuran keuangan desa.

Peraturan Menteri dalam Negeri No 113 Tahun 2014 tentang pngelolaan keuangan desa

Peraturan Menteri Dalam Negeri (Pemendagri), No.113 tahun 2015 tentang Pengelolaan Keuangan Desa.

Peraturan Menteri Desa, Penetapan Prioritas Penggunaan Dana Desa Tahun 2015 Nomor 5 Tahun 2015

Rasul, Syahrudin, 2014;11. Pengintegrasian Sistem Akuntabilitas Kinerja dan Anggaran. Jakarta: Detail Rekod.

Sulistiani dalam Subroto, 2011. Transparansi dan Akuntabilitas Penyelenggaran Pemerintahan. Jakarta.

Sintia Ayu, 2012. Skripsi Pull. Tentang transparansi sebagai fasilitas penyebaran informasi dalam kegiatan melayani. Bandung.

Soetardjo, 2015. Tentang Administerasi posisi desa dalam kewenangan keberagamaan. Bandung: Alfabeta.

Sugiyono, 2017:8. Metode Penelitian Kombinasi. Bandung: Alfabeta.

Solekhan, 2012:15. Penyelenggaraan Pemerintahan Desa Berbasis Partisipasi Masyarakat dalam Membangun Mekanisme Akuntabilitas. Malang: Setara Press.

Sri Lestari, 2016. Angket Koesioner Penelitian Kuantitatif. Jakarta

Sebastian Yuda, 2016. Jurnal Skripsi. Tentang pengaruh prisnsip transparansi dan akuntabilitas dalam pengelolaan APBDesa Di desa Karangrejo.

Sumpeno, 2011:222. Perencanaan Desa Terpadu. Banda Aceh: Read.

Sugeng Praptoyo, 2015. Kemitraan dan model-model pemberdayaan. Yogyakarta: Gava Media.

Swith, Max George, 2010. Principals and Agents: An explanatory model of public budgeting. Journal of Public Budgeting and Financial Management (Fall): 325-353. 
Solekhan, M. 2012. Penyelenggaraan pemerintahan desa berbasispartisipasi masyarakat dalam membangun mekanisme akuntabilitas. Malang: Setara Press.

Syachbrani, 2014 Pengertian tentang Desa dan pemahaman desa. Jakarta. Salemba Empat.

Sugiyono, 2012:116. Memahami Penelitian Kualitatif. Bandung: Alfabeta.

Syarudin Rasul, 2002:11. Dimensi Akuntabilitas. Jakarta. Salemba Empat.

Subroto, 2011, dalam Sulistiani, 2011, transparansi dan akuntabilitas sebagai kunci penyelenggaraan pemerintahan. Jakarta.

Thomas, 2013:12. Pengelolaan Alokasi Dana Desa dalam Upaya MeningkatkanPembangunan di Desa Sebawang Kecamatan Sesayap Kabupaten Tana Tidung. Dipublikasikan. Skripsi. Program S1 Pemerintah Integratif. Fakultas IImu Sosial dan IImu Politik. Universitas Mulawarman.

Teguh Kurniawan, 2011 dalam Lalolo, 2011:17. Akuntabilitas financial. Jakarta.

Undang-Undang No. 6 Tahun 2014 tentang desa.

Undang-undang NO, 22 Tahun 1999 Tentang Pemerintah daerah.

Undang-undang No. 25 Tahun 1999 tentang Pengembangan keuangan pemerintah pusat dan daerah. Undang-Undang Nomor 32 Tahun 2014 tentang Pemerintah Daerah.

Virgie, Dkk. 2013:97. Tentang pengelolaan keuangan desa dalam kebijakan desa. LIPI. Press.

Wahyudin, 2015:130. Metodologi Penelitian Bisnis dan Pendidikan. Semarang: Unnes Press. Edisi 1

Zyen, Elvira, 2011. Pengaruh Penerapan Good Governance dan Standar Akuntansi Pemerintahan Terhadap Akuntabilitas Keuangan. Trikonomika, 10 (1): 52-62 